\title{
Alleviation of Poverty among OIC Countries through Sadaqat, Cash Waqf and Public Funding
}

\author{
Yusuff Jelili Amuda and Nor Azizan Che Embi
}

\begin{abstract}
This paper discusses the design of an efficient and optimal cooperation and unity among OIC countries for the integration of waqf properties and sadaqat and public funding as a viable instrument to alleviate poverty rate among Muslims globally. Poverty is rampant and common among Muslims globally and their financial constraints call for urgent, collective and concrete efforts among OIC countries to improve the conditions of poor Muslims regardless of their colour, gender, nationality, and sect since Islam simplifies unity. The study analyses the types and nature of investment that can be invested in with integrated charities such as waqf properties, sadaqat and public funding to create employment in order to reduce the poverty rate in concerned and targeted nation. It will further analyze how the financial status of Muslims can be improved.
\end{abstract}

Index Terms-OIC countries, poverty, Waqf property, Sadaqat, public funding and alleviation.

\section{INTRODUCTION}

Poverty is rampant and common in the Muslim world. Inequality and low productivity have contributed to poor standards of living. The large number of Muslims in Africa, Asia and Middle East are living below \$2 a day due to their abject and absolute poverty. In fact, the Muslim community accounts for a significant number of poor and less privileged globally. This raises many questions that require answers and solutions to the problems confronting the Muslim world [1]. The question is why are Muslims poor? Are they created to be poor? Is it because of their culture or faith? It is because of their selfishness? What is the solution to the financial constraint of Muslims? Who is responsible to the financial predicament of Muslims? Answers to all these questions will be provided in the analysis. This present study discusses how to liberate Muslims from abject, absolute, and chronic poverty based on the legal maxim that hardship must be removed or hardship begets facility.

The present situation of some Muslims is worsening due to their financial limitations and poverty as a result of uncontrolled corruption. The economic meltdown calls for practical and physical approaches to reduce the poverty rate. The financial challenge affecting many Muslims has a negative impact on their lives mentally, socially, morally, and religiously and requires a collective solution. The reason is that the majority of them cannot provide adequate provisions for their immediate family due to financial constraints. It is an undeniable fact that many people engage in illegal and

Manuscript received June 25, 2013; revised August 26, 2013.

Yusuff Jelili Amuda is with Department of Finance, Kulliyyah of Economics and Management Sciences International Islamic University, Malaysia (e-mail: yusuffyja@iium.edu.my, akorede4@yahoo.com, izanebbm@yahoo.com). unlawful business and transactions that are lucrative because they are mindless about their religion and faith. According to Islamic principles, all actions are considered forms of devotion and Muslims are urged and commanded to desist from any unlawful and illegal business and transaction regardless of being lucrative or profitable. The huge profits should not be used as a basis for wrong doings or disobeying the commands of the Creator.

There are many lawful and profitable businesses and transactions that one can engage in if there is enough working capital to run the business. With the present financial condition of many Muslims around the globe, there is a need for the alleviation of poverty through waqf properties, sadaqat, and public funding. Poverty alleviation needs financial systems in the form of small and medium enterprises, investment, large scale enterprises, and partnerships, micro financing, interest free loans, gifts, commercialization, lawful businesses, agriculture, construction, factories, and other profitable investments.

\section{FACtORS THAT INFLUENCE POVERTy AllEVIATION AMONG THE OIC COUNTIES THROUGH WAQF PROPERTIES, SADAQAT, AND PUBLIC FUNDING}

There are many factors that influence the integration of waqf properties, sadaqat, and public funding among the OIC countries. Poverty is rife and there are large numbers of needy Muslims. Their financial conditions require collective efforts to ease their hardships.

\section{A. Poverty}

Poverty is rife and common in every part of the globe and even in the developed world the lives of many adults and children are fraught with deprivation [2]. Poverty can be categorized into absolute poverty and relative poverty. Absolute poverty refers to a certain minimal living standard which is specified in terms of nutritional level, clothing, and the income required to support an individual [3], [4]. Relative poverty has been defined and interpreted in relation to the prevailing living standard of a society, recognizing explicitly the interdependence between the poverty line and the entire income distribution [5]. Based on the poverty theory, many Muslims in Africa, Asia, the Middle East to name a few places are facing both absolute and relative poverty due to the rate of poverty and many of them cannot afford to feed themselves and their families adequately because of their low incomes and the size of the family [6]. Many adults and children find themselves living in trying conditions due to their low family incomes. The rate of poverty in the Muslim world is alarming where many men, women, and children are not able to eat well. Many are engaging in illegal and unlawful businesses by way of necessity while some under 
aged children flock to the labour market to survive and also to assist their unemployed or aged parents. Many leaders in Muslim countries are the architects and root cause of the poverty in their respectful countries due to their selfishness because there are no concerted efforts to fulfill their promises which they made before and after being elected as leaders. The leaders should be conscious of the trust given to them for which they are answerable in the hereafter. They must desist from any kind of wickedness and unjust attitudes towards their fellow citizens.

Despite this, many Muslim philanthropists have the potential to change the lives of many of the less privileged. They can empower them through waqf properties, sadaqat, and public funding regardless of their colour, gender, nation, and sect. If rich people stop their extravagant expenses and begin thinking of the needy fellow Muslims, the world will be put on the track of concrete reform. It has been stated repeatedly in the Holy Qur'an that wealth is from Allah and must be spent to relieve those who are in need and suffering because it is a good deed and has advantages for both the recipients and givers [7].

"That man can have nothing but what he strives for. That (the fruit of) his striving will soon come in sight".

It is the duty of Muslim scholars to contribute to the lives of the less privileged by educating and encouraging those who are capable to support the poor Muslims around the globe. The ways and methods to transfer the donated properties to the needy should be suggested by the scholars and the management of charities. Similarly, scholars have to preach against racism, selfishness, extravagance, unkindness, and niggardly attitudes among Muslims. Muslims should see themselves as one and unity must be maintained.

\section{B. High Number of Needy Muslims}

The number of needy Muslims differs from one country to another. The alarming number of needy Muslims requires concerted efforts to seek for effective approaches and mechanisms to alleviate their hardships. One such strategy is the integration of waqf endowment, sadaqat, and public funding. Due to the significant number of needy Muslims, there is need for transferring charities from rich countries to developing Muslim countries. Public awareness should be promoted especially among the rich of the contribution to waqf endowment, sadaqat, and public funding to reduce social problems among fellow brothers and sisters. For example, it has been argued and estimated that there are more than 580 million needy Muslims in Bangladesh, Egypt, Indonesia, Nigeria, and Pakistan. Similarly, Afghanistan, Niger, Mozambique, Sudan, and Turkey account for more than 600million of global poverty. In addition, Indian Muslims are estimated to be more than 150 million and Russian Muslims are estimated at more than 29 million. This study argues that the large number of Muslims should be exploited and utilized to empower the Muslim community through business, agriculture, farming, small and medium enterprises, factories, and other profitable investments. With the precarious financial situation of Muslims around the world, viable and able institutions like waqf endowment should take up the challenge for the global collection of waqf properties, sadaqat, and public funding. There must be a kind of networking among waqf endowments in each country that should be monitored by IDB [8]. Working as a team will promote greater awareness of the social problems confronting each county and help determine the way forward to put an end to poverty. The level of poverty in the Muslim society is beyond fragmented financial help but requires massive financial assistance through the said charities. Although, no institution can completely eliminate poverty, yet endowments are capable of assisting a large number of applicants in as much as there are sufficient donated properties and that such properties are managed properly and effectively.

\section{Aims OF INTEGRATING WAQF PROPERTy, SADAQAT, AND PUBLIC FUNDING}

The main philosophical objective for donating waqf properties, sadaqat, and public funding is the contribution towards any action that merits the pleasure of Allah the Almighty. Since the objective of the said charities is to render assistance or support that would be rewarded by Allah, the distribution of such charities can differ from one place to another due to the varying needs of the less privileged [9]. However all such activities are considered devotional acts that benefit the founder, payer and beneficiaries in as much as the collection and distribution of collected properties is in line with Islamic principles [10]. Less privileged students can be sent abroad to study any needed disciplines that will benefit the Muslim society. Waqf schools, colleges, and universities can be built with collected charities in order to educate less privileged Muslims. Clinics or hospitals can also be built in needy countries with integrated charities for the convenience of people without access to medical treatment due to the high costs. The creation or stationing of mobile clinics will also create jobs for nurses and doctors. The institution in charge of collection of the said charities can utilize the properties to alleviate poverty among the Muslims through empowerment.

\section{HindRANCES IN THE COLLECTION OF WAQF PROPERTy, SADAQAT, AND PUBLIC FUNDING IN MUSLIM COUNTRIES}

There are a number of factors hindering the collection of the said charities in Muslim countries despite the fact that Muslims are the majority in OIC countries such as Bangladesh, Egypt, Indonesia, Nigeria, Pakistan Afghanistan, Niger, Mozambique, Sudan, and Turkey. The following is a discussion of the hindrances impeding the collection of waqf properties, sadaqat, and public funding by authorized establishments in many Muslim countries:

\section{A. Lack of Awareness and Ignorance}

Lack of awareness of many Muslims in general and philanthropists in particular in some countries towards the importance of the establishment of waqf, sadaqat, and public funding is a major obstacle. With the global financial meltdown, strong charitable institutions are needed to reduce the social and financial difficulties confronting many Muslims in their respectful countries. Due to their ignorance of charitable institutions, many philanthropists spend their wealth in other directions. The question is why have Muslim 
scholars failed to educate the rich on the importance of charity and the role of charitable institutions? The ignorance of Muslim philanthropist of the importance of waqf can be attributed to the failure of Muslim scholars due to their selfishness and failure to preach the importance of waqf, sadaqat, and public funding in their mosques, during Friday prayers, and Islamic functions and events. If the Muslim philanthropists in each country are well educated and well informed of the importance of collective or joint efforts towards the collection of the said charities and contributing to the needy, the accumulated properties would be channeled to the appropriate quarter and it will be well managed by qualified and competent mutawalli or administrators nationally and internationally. It is believed that collective efforts by transferring collected charities from less needy countries to needy nations will contribute significantly to poverty reduction among Muslims. No single persons can address the issue of poverty, and as such Muslims should come together and give part of their properties as waqf, sadaqat, and public funding in order to contribute to the Muslim society for which many lives would be changed socially, physically, mentally, religiously, and morally. But due to the ignorance and lack of awareness of the rich, social responsibilities are left unaddressed and the lives of many are left to suffer. To rescue and educate philanthropists, there is need for the establishment of able and viable charitable institutions in Muslim countries at local government, state, and federal levels to manage the gifted properties judiciously in the interest of needy Muslims [11].

\section{B. Change of Ownership}

Changing ownership of the donated and gifted property is another problem that might confront charitable institutions in many counties. The administrator or management may be greedy and work contrary to Islamic principles in changing the ownership to their personal property, and as such there is a need to maintain honesty and sincerity in charitable institution or waqf endowment institutions globally. For this there must be rules and regulations on waqf, sadaqat, and public funding drafted and endorsed by the Islamic Development Bank. If there are effective laws to guide charitable institutions like waqf endowment across the Muslim world and punishment is spelled out in the provision, the management will act according to the rules and regulation while the primary goals of collected or donated charities will be materialized. Lawlessness will be controlled and the needy would be assisted and financially aided through the said funds. In addition, the institution would be able to empower a large number of unemployed adults throughout the Muslim world. On the other hand, the management and staff need to be extra careful in carrying out their tasks such as distributors, contractor, farmer, driver, seller, debtors, and others when they are well aware of the consequences of their act [12].

\section{Miserliness or Selfishness}

Some of the rich in Muslim countries are well aware of the importance of waqf, sadaqat, and public funding socially, religiously, mentally, physically, and morally. Despite their properties and bounties they refuse to assist others due to their miserliness and fear that their money will finish and find it difficult and cumbersome to give charity to needy people.
Religiously, contribution to waqf or giving sadaqat or public funding is a voluntary act and there is no specific amount to be given out as sadaqat unlike zakat. Nevertheless, the social problem is the responsibility of those who are capable to render assistance to those who are seriously in need. Therefore, Muslim scholars need to educate the society on the importance of waqf, sadaqat, and public funding and donating their property to empower the poor [13].

\section{Political Influence in Management Appointment}

Another plight that might face the establishment and integration of waqf, sadaqat, and public funding in Muslim nations is the political influence present in appointing the management of such institutions where the incompetent might be appointed to pilot the affairs of Islamic charitable institutions. This can be seen in the pilgrims' board member appointment or other Islamic institutions where some members are not qualified but due to their political connections or influence, they were appointed and they mismanaged the office. Any issue related or connected with religion is a sensitive issue and cannot be politicized and the credible candidate should be appointed to run the affairs of Islamic institutions. The creation of waqf endowment requires scholars knowledgeable in waqf, Islamic economics, Islamic banking and other related science that would be useful for the creation of waqf as a social need of communists. When the competent and qualified management are appointed, they will educate the society on the values and importance of waqf through their services that benefit the less privileged and also help philanthropists to channel their properties to the right institution. When wealthy people know the capability of waqf to maintain their properties according to their expectations in line with Islamic principles; they will voluntarily and willingly donate more and attract others to join them in donating to the waqf as a social institution. If ignorant people are appointed, there is a tendency to mismanage the properties and working contrary to the waqif rules and regulations will result in the closure of the institution due to alleged crimes and atrocities [14].

\section{E. Lack of Proper Implementation}

Proper implementation of waqf, sadaqat, and public funding can only be achieved and materialized if there is proper and effective implementation of waqf administration and disbursement of collected charities or property in line with Islamic principles. Therefore, the management must be well qualified and up to the task to shoulder the responsibilities of their duty. The management must also be aware of the rules and regulations related to transactions, business, partnerships, microfinance, commercialization, free interest loans and investment. They must be aware of Islamic principles and rules regulating loans, agriculture, harvest, livestock, poultry, renting, transportation, small and medium enterprises and other lawful lucrative transactions. If the management fails to implement the charities' property properly, there would be negative development concerning the efforts to liberate and free Muslims from poverty and the main goals of waqf, sadaqat, and public funding would not be realized and achieved [15].

\section{F. Readiness of Muslim Nations}

Readiness can be discussed in two ways, namely readiness 
of the waqif (donor) and readiness of each country to manage and transfer the collected charities to other needy Muslim countries. If the waqif is well prepared, determined, dedicated and intended to donate part of his or her property for waqf, sadaqat, and public funding for needy Muslims in general regardless of country, tribe, gender, sect, and color, then wealth will be distributed and shared within the society. Similarly, the management should be ready to work around the clock on how to alleviate poverty from the Muslim world by invest the donated property in profitable and lucrative business and other investments that will generate money for the institution. Then, the aims and initial objectives of collection and integration of the said charities together would be achieved in eliminating poverty and many beneficiaries would be well empowered and able to provide adequate provisions for their immediate family.

\section{Solutions to Muslim Plights}

It has been previously explained and analyzed that collected property can be used to empower needy and less privileged Muslims educationally, socially, physically, religiously, morally and financially. Many Muslims who are in need can be empowered through small and medium enterprises and also via big and large scale enterprises in so long as the investment or business activities are in line with Islamic principles and the purpose of the collected charities is achieved. Creation of business centers, industries, factories, small and medium enterprises, learning institutions, petrol stations, halal companies and industries, vehicles for commercial transportation, bakeries, farms, poultry, fisheries, and other transactions that require employment will create jobs for needy Muslims. The above said businesses and investments require large capital that needs viable institutions to provide the working capital. The capital can be realized from integrating waqf properties, sadaqat, and public funding among the OIC countries to relieve needy Muslims [16]. The following are proposed ways to alleviate the poverty among Muslims through empowerment:

\section{A. Establishment of Zakat, Sadaqat and Public Funding Institutions}

It has been previous mentioned that many Muslims are extremely and abjectly poor. In order to alleviate poverty in Muslim nations, there is a need for sufficient resources such as movable or immovable properties to assist those who are in need. Subsequently, in order to have enough income to cater for needy Muslims, there is a need for the creation and establishment of strong institutions in each country that will be responsible for waqf, sadaqat, and public funding to assist and finance Muslims globally. Such institutions will be answerable to the IDB for quarterly or annual reports for the smoothness and progress of the institution. This will give IDB ample opportunity to be aware of the financial condition of fellow Muslims all over the world and to prompt solutions where needed. It is the duty of the management to survey and priorities the needs of poor Muslims in their respectful nation and how to empower them through the small and medium enterprises or any other lucrative transactions and business. Furthermore, it is the duty of the institution to think of creating jobs for unemployed fellow Muslims [17].

\section{B. Agriculture}

Islam preaches consumption of lawful and permitted food but there must be a provision for available and accessible foods in Muslim society in order to protect them from taking unlawful food. With the percentage of less privileged and unemployed Muslims in each country, there is an ample opportunity for the institution in charge of charities to use part of their immovable properties such as idle and fertile land for agriculture such as cultivation, farming, cattle rearing and poultry. For instance, the percentage of needy Indonesian Muslims can produce sufficient agriculture products. The same methods are applicable in other continent such as Nigeria. Of course the institution has to utilize all donated lands judiciously and according to the needs of Muslim countries. Therefore, the institution like waqf endowment can use the collected charities to purchase modern farming equipment and machineries that would be useful for agriculture or farming in order to empower the less privileged. The institution can open small and medium enterprises and factories to produce drinkable juice which will also create jobs for needy Muslims. Farm products can be also be sold to other countries regardless of their faith and religion. Some countries can plant palm oil or rear cattle such as cow, sheep, ram, vows, chicken, fisheries, and other lawful and legal farming that will create job opportunities [18].

\section{Investment}

The Islamic charitable Organization in any Muslim country responsible for integrating the charities together can invest the collected capital in any profitable investment in order to generate income to assist needy Muslims. The investment might be in petrol stations, factories, cement companies, oil and gas companies, lawful drinkable companies, and other lucrative investments [19].

\section{Inclusion of Charities for Micro-Finance in Muslim Nations}

Charitable institutions responsible for waqf property, sadaqat, and public funding will act as financial institutions where capital will be given to needy Muslim who approached the institution indicating his or her intention to engage in business but due to lack of capital and their financial constraint, he or she is unable to do the intended business. The applicant will be assisted in his or her intended entrepreneurship where the assistance will be informed of capital and equipment to run the business. Giving the needy Muslims the sufficient amount of money based on the agreement that will remove financial plights from the applicant in the future will be highly appreciated and commendable. When households are empowered, then, the poverty will alleviate gradually. Integrating all collected funds together to provide working capital to the needy who are skillful and trained in buying and selling of saleable raw materials and others relevant commodities or goods presumed to transform many lives positively. However, the institution is required to organize training and workshops in order to educate intended less privileged Muslim on the nature of entrepreneurship. The training will prepare them for the challenges and how to overcome challenges [20].

\section{E. Education}

Historically, educating people is one of the objectives and 
aims of waqf where waqf properties were used to educate many people in order to develop them mentally, physically, spiritually, and economically. Many teachers were employed to teach students and they used waqf properties to pay their salary. If the collected charities were insufficient to build the schools, colleges, tertiary institution, then, the institution can invite developers to participate in the project. The institution can invite the developer to develop big projects such as schools, colleges or tertiary institutions where the developer will collect the cost and profit margin for the agreed period. However, the percentage that will go to the charitable institution can be used to cater for needy registered Muslim student in the school, colleges, and tertiary institution until the property ownership is transferred to the Islamic charity. This will reduce poverty in society and will protect future financial plight among Muslims. Many students need financial support for which waqf properties can be diverted to cater for many drop out students while some educational programs can be introduced to educate women and the elderly. At the end of the contract, the property will be fully controlled by the institution because the ownership has been transferred and changed to the Islamic endowment [21].

\section{F. Small and Medium Enterprises}

It has previously been explained that management should properly collect and manage the charities. The institution can establish small and medium enterprises dealing with building construction, road construction, house wiring, roofing, and other related activities that will create jobs for needy Muslims [22]. The company will purchase all needed equipment with collected charities to create jobs for competent and qualified unemployed Muslims. Based on that, some adult Muslims will have the opportunity to be employed in such small and medium enterprises. The duty and responsibility of charitable institutions is to monitor the smoothness of the company and encourage the benefactors to employ fellow needy Muslims in their SME in order to reduce poverty in society. Needy Muslims can request from the institution to finance his or her small and medium enterprise where profitable and lucrative business will be made for selling. After all the necessary feasibility tests and procedures have been studied and consciously evaluated, the institution can finance such small and medium projects on the agreement that benefactor will pay the money back over the agreed period to the institution in the interest of other needy Muslims. This is will pave the way for greater job opportunities for unemployed Muslims. The problem of accommodation is a major problem confronting many Muslims. Charitable institutions can covert gifted lands to build affordable housing for low income Muslims. Many beneficiaries would be happy and appreciate the institution for such a provision. The accommodation can be rented, sold or leased where the occupant will enjoy the house and institution in charge will benefit from returns and invest it into lucrative business. The accommodation can be built on waqf land with cash waqf, sadaqat, and public funding money.

\section{CONCLUSION}

There are many verses from the Qur'an and Sunnah that encourage helping and assisting others Muslims who are in need financially, medically, morally, and religiously. The institution in charge of collecting charities must consciously deal with trusted properties such as waqf properties, sadaqat, and public funding. This paper strongly believes that integrating the said charities will help many less privileged Muslims if the charities are managed properly. The institution in charge of collection should also strive to invest in lucrative businesses that will benefit Muslims. The philanthropists Muslim should extend their wealth into the institution in their respectful countries in order to be used for needy Muslims. Similarly, the accumulated or un-needed properties can be transferred from one Muslim country to another to assist poor Muslims. This is based and deduced from Governor Muadth Ibn Jabal who sent the collected zakat from Yemen when he was governor to Caliph Umar Ibn Khattab to be distributed to the less privileged in Medina because there were no needy people or poor Muslims in Yemen. The bottom line is that the collected charities can be transferred from less needy Muslim countries to needy Muslim countries to support them.

\section{REFERENCES}

[1] M. Obaidullah, Fighting against Poverty in Islamic Societies Islamic Voice Search, December 2007.

[2] F. Michael, The Moral Status of Children: Essays on the Rights of the Child, USA: Kluwer Law International, 1997, pp. 85-86.

[3] S. M. Hashim, Income Inequality and Poverty in Malaysia, New York: Rowman \& Littlefield publishers, INC, 1998, pp. 37-39.

[4] S. Ahmad, Inequality and poverty in Malaysia: Measurement and Decomposition, London: Oxford University Press, 1983, pp. 113.

[5] J. Gree, "A Methodology for measuring food poverty applied to Kenya," Journal of Development Economics, vol. 24, no. 1, pp. 59-74, 1986.

[6] R. Schubert, "Poverty in developing countries: its definition, extent and implication," Journal of Economic, vol. 49-50, pp. 17-40, 1994.

[7] A. A. Dirisu, The Islamic Concept of Social Justice, Pakistan: Islamic Ltd, 1984, pp. 122-123.

[8] A. K. Qandooz, "The role of Awqaf in providing public services," Journal of Awqaf, no. 16, pp. 80-92, May 2009.

[9] A. Z. Muhammad, Alajhaha Al-Islam Muharat Fi Al-Waqf, Cairo, Egypt: Daar al-Fikri al-Arabiy, 1971, pp. 53-54.

[10] M. S. Jaldeen, The Muslim Law of Succession Inheritance and Waqf in Sri Lanka, Colombo: The Federation of Associations of Muslim Youth in Sri Lanka, 1993, pp. 283.

[11] M. F. Karim, "Problems and prospects of Awqaf in bangladesh: A socio-legal perspective," in Proc. International Conf. on Waqf Laws and Management: Reality and Prospects, International Islamic University Malaysia, Kuala Lumpur, October 20-22, 2009, pp. 4-12.

[12] M. I. A. Mohsin, "Family Waqf: its origin, law prospects," in Proc. International Conf. on Waqf Laws and Management: Reality and Prospects, International Islamic University Malaysia, Kuala Lumpur, 2009, pp. 3-6.

[13] M. Khaf, "Role of Zakat and Awqaf in reducing poverty: A case for Zakat-Awqaf-based institutional setting of micro-finance," in Proc. International Conf. on Poverty Reduction in the Muslim Countries, Dhaka, 2006, pp. 12-13.

[14] A. E. Sarker and M. H. Rahman, "The emerging perspective of governance and poverty alleviation: a case of Bangladesh," Public Organization Review, vol. 7, pp. 93-112, 2007.

[15] S. A. Karim, "Contemporary waqf administration and development in Singapore: challenges and prospects," in Essential Readings in Contemporary Waqf Issues, M. Khaf and S. M. Mahamood, Eds. Kuala Lumpur: Cert publications Sdn. Bhd, 2011, ch. 5, pp. 113-123.

[16] A. Trakic. "The legal and administrative analysis of Waqf in Bosnia and Herzegovina," in Proc. International Conf. on Waqf Laws and Management: Reality and Prospects, International Islamic University Malaysia, Kuala Lumpur, 2009, pp. 4-9.

[17] M. Khaf, "Role of Zakat and Awqaf in reducing poverty: A case for Zakat-Awqaf-based institutional setting of micro-finance," in Proc. International Conf. on Poverty Reduction in the Muslim Countries, Dhaka, 2006, pp. 12

[18] R. H. Nawawi, Islamic Law on Commercial Transactions, Malaysia: CT Publication, 1999, pp.146-149. 
[19] M. I. A. Mohsin, "Cash Waqf a new financial product model aspects of shariah principles on ITS commercialization," presented at Islamic Banking, Accounting and Finance Conference (Ibaf), The Legend Hotel, Kuala Lumpur, July 28-29, 2008.

[20] A. N. Sarker and J. Singh, "Savings-led microfinance to bank the unbankables: sharing of global experience," Global Business Review, vol. 7, pp. 271, 2006.

[21] R. Sukmana, M. Kholid, and K. A. Hassan, "Waqf management through sukuk Al-intifa'a: A generic model," Awqaf Journal, no. 17, pp. 11-13, 2009.

[22] S. I. Owualah, Entrepreneurship in Small Business Firms, Lagos: G-Mag Investment Limited, 1999, pp. 10-15.

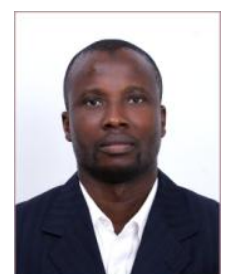

Yusuff Jelili Amuda was born in Ibadan Oyo State, Nigerian. He studied and obtained his B.A. in Shariah from Al-Azhar University, Cairo Egypt and completed his master and doctoral in comparative Laws at Ahmad Ibrahim Kulliyyah of Laws, Malaysia. He later absorbed as senior lecturer at Sultan Idris Education University, Malaysia between 2010-2012. Yusuff is currently lecturing at Kulliyyah of Economics and Management Sciences, Malaysia as a senior lecturer. $\mathrm{He}$ has published numerous articles in reputable local and international journals such as International Journal of Sustainable Development, Scopus, Lambert Academic Publishing, Shariah Law Report, Journal of Islamic Law Review, Malaysian Law Journal, Journal of Al-Risala, Procedia-social and Behavioral Journal, and International Journal of Social Policy.

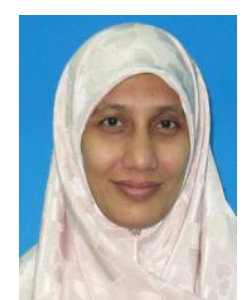

Nor Azizan Che Embi has served International Islamic University Malaysia since 1997. Prior to joining International Islamic University Malaysia, she worked in Central Bank of Malaysia as an examiner/auditor for commercial bank. She holds diploma in Banking from Mara Institute of Technology, Malaysia. She obtained her bachelor science in Finance from Oklahoma City University, USA and received her master in Business Administration with major in Finance from University of Malaya. She obtained her doctorate in Business Administration (Finance) from National University of Malaysia (UKM). Her current research in the area of Shariah-compliance screening on stock market has won a gold medal in IIUM research, Invention and Innovation Exhibition 2013. 